\title{
A Review on Impact of Chicken Egg Shell Powder on Strength Characteristics of Cement Concrete
}

\author{
M.S. Sugirtha ${ }^{1}$, K. Sargunan ${ }^{2 *}$ \\ ${ }^{1}$ PG Student, Department of Civil Engineering, KSR College of Engineering, Tiruchengode, Tamil Nadu, India. \\ ${ }^{2}$ Assistant Professor, Department of Civil Engineering, KSR College of Engineering, Tiruchengode, Tamil Nadu, \\ India. \\ *Corresponding author E-Mail ID: sargunanksr@gmail.com
}

Doi: https://doi.org/10.34256/irjmtcon55

\begin{abstract}
This paper summarizes the upshot of various research papers deals with the investigations on cement concrete proportioned with eggshell powder as a substitute mantle for cement. Although, it aims to understand the approaches covered by main research streams in area so as to highlight the advantages and uses of calcium rich material. Developed, developing countries nowadays exploits the potentiality of chicken eggshell powder and in a way they were fruitfully cast it on as an ingredient of animal and poultry feed, land fertilizer and even an excellent substitute option in construction industries. These marginal usages fed in to the minimization of open land disposal scenarios which associates landfill problems, human and environmental health issues. This paper briefly reveals the investigations endured on strength and structural characteristics of conventional cement concrete that are evenly proportioned with calcium rich eggshell powder and their potential feasibilities were exemplified.
\end{abstract}

Keywords: Eggshell powder (CaCO3), Eggshell ash (CaO on incinerated, Strength characteristics

\section{INTRODUCTION}

Eggs are been predominantly used by humanity in large scale and also small scale industries all over the world and the egg shell waste is commonly disposed without any pretreatment in landfills because it is traditionally futile. Meanwhile egg shell is treated as natural solid waste which is non hazardous, that tang may attract worms and rats, that pretense health crisis to the public. There are many types of disposal such as land fill, open burning, drains clogged up with rubbish and river fill. The outlay for waste disposal is expensive due to the scarcity of land and through large amount waste disposal there pose a contamination in ground water. Therefore, the ways should be found to utilize the waste efficiently by recycling.

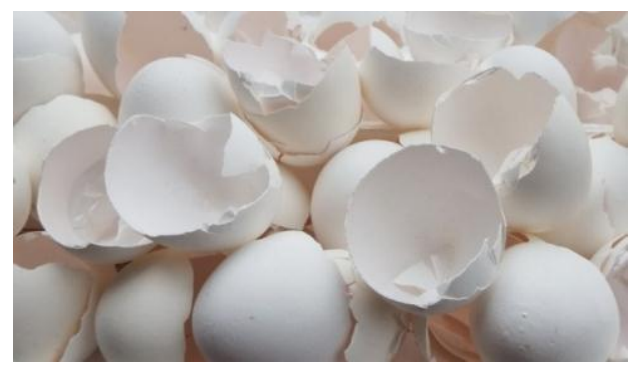

Fig 1. Egg shells 
Nowadays the waste products from food manufacturing industries are recycled and are used in construction industry to maximize the profit while reducing the amount of construction budget. Egg shells are known to have good strength characteristics when mixed with concrete. Thus eggshells are applicable for the development in construction industry.

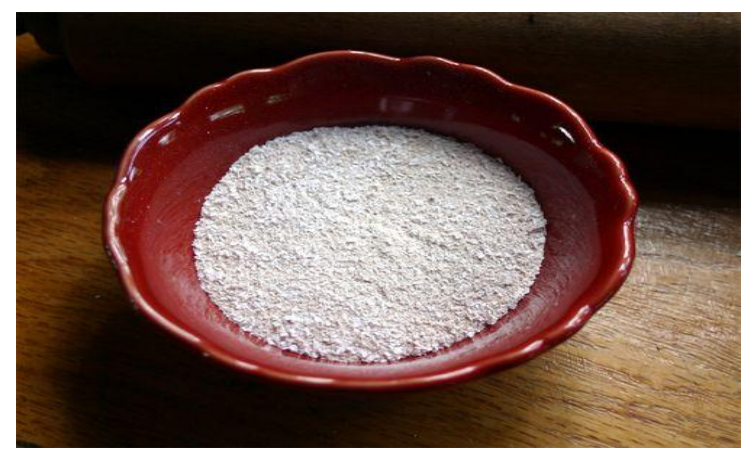

Fig 2. Egg shell powder

\section{LITERATURE REVIEWS}

Gowsika et al.,(2014) experimentally investigated on eggshell powder (ESP) as partial replacement with cement in concrete. The chemical composition and strength properties of ESP in cement mortar was determined at 28 days curing period by replacement of ESP at 5, 10, 15, 20, $25,30 \%$ by weight of cement with mix proportion 1:3. In compressive strength there was a sharp diminish beyond 5\% ESP substitution and so to bump up the strength, admixtures like saw dust ash, fly ash and micro silica are been used. It was found that replacement of 5\% ESP with $10 \%$ micro silica contributes high strength of hardened concrete when compared to conventional concrete. [1]

Amaranth Yerramala et al., (2014) investigated the properties of concrete with eggshell powder as cement replacement. The different properties of hardened concrete have been investigated at $7^{\text {th }}$ day and $28^{\text {th }}$ day curing period on replacing 5, 10, 15\% of ESP for cement and tests were determined. Further result shows that addition of fly ash along with ESP up to 15\% is beneficial than control concrete. The absorption property decreased with decrease in permeable voids.Sorptivity decreased with strength and increased with water absorption.[2]

Mohd Ali Khaled et al., (2014) studied the behavior of eggshell powder as partial replacement of cement in concrete. In this paper partial amount of cement is replaced by eggshell powder as $5 \%$ increment up to $30 \%$ by weight and strength characteristics at end of 28 days is noted down. To obtain the strength that decreased beyond 5\% are enhanced by replacement of some mineral admixtures namely fly ash, micro silica and saw dust. By this scenario it is found that $5 \%$ of ESP with $10 \%$ micro silica, fly ash, saw dust replacement increase the strength property of concrete. [3]

Praveen Kumar et al.,(2015) experimentally studied on partial replacement of cement with eggshell powder. To study the strength parameters M30 concrete is designed for various combinations, ESP is replaced by 10, 20, 30\% with silica fume by 5, 10, 15\% and tests are been undertaken at $7^{\text {th }}$ day and $28^{\text {th }}$ day of well cured specimens. It was observed that the strength increase up to $15 \%$ without the addition of silica fume as addition of silica fume also enhance the strength, but in economical vise ESP is only enough for getting higher strength. [4]

Dhanalakshmi et al.,(2015) has presented a comparative study on eggshell concrete with partial replacement of cement by fly ash. Here two wastes are used as partial replacement to cement and various properties were gathered. Increase in density and workability was found with addition of fly ash to optimum ESP concrete. [5] 
Mohamed Ansari et al., (2016) studied the replacement of cement using eggshell powder. The characteristics were carried out for concrete replaced with 10, 15, and $20 \%$ of ESP replacement in cement. From the results it is proved that replacement of ESP about 10 to $15 \%$ is effective, on further addition there is weaken in strength. [6]

Monisha et al., (2016) experimentally investigated on concrete using eggshell powder and polypropylene fiber. This paper derives the usage of ESP $20 \%$ and polypropylene fiber in range of $0,0.2$ and $0.4 \%$ as replacement of fine aggregate. The strength properties obtained are compared with conventional concrete at 7,14 and 28 days of curing period. The test results shows that, optimum strength was obtained at $20 \%$ of fine aggregate replaced by ESP and $0.2 \%$ of polypropylene fiberby the weight of concrete for M20 grade. [7]

Nurul Shahadahtul Afizah Asma et al.,(2016) studied the mechanical properties of concrete using eggshell ash and rice husk ash as partial replacement of cement. This research was carried out to determine the optimum percentage of eggshell ash (ESA) and rice husk ash (RHA) as partial cement replacement. The samples were tested with proportions of 2:8, 4:6 and 6:4\%. By review on previous researches, the strength of concrete reduced with eggshells, thus to increase the strength RHA is introduced into mix design. The result is found due to high content of amorphous silica in ash. [8]

Bysani Mythili et al., (2017)studied on Limited Substitution of egg shell powder with cement in concrete. This project reports the results of experiments evaluating the utilization of ESP at replacement of $5 \%$ up to $30 \%$ by weight of cement. The admixtures used are saw dirt ash and small oxide to reinforce the strength of concrete combined with 5\% ESP, by final result of dissertation indicates that replacement of 5\% ESP with $22 \%$ of micro silica are often superimposed with none reduction in strength properties of typical cement. [9]

Divya et al.,(2017)investigated on cement concrete mixed with egg shell powder. The experimental inquiry consisted by 5, 10, 15 and 20\% of ESP as partially replaced with ordinary Portland cement and strength for $7^{\text {th }}$ and $28^{\text {th }}$ day tests were determined. Replacement up to $15 \%$ is affordable. [10]

Priyanka et al.,(2017)experimentally investigated on eggshell powder and rice husk ash as partial replacement of cement. This paper summarizes the research work on the properties used as a partial replacement of RHA 10 and 15\% with ESP 4 and 5\% of cement. The strength tests are carried out on hardened concrete after 28 days of curing. Better properties are obtained with replacement of cement in rice husk ash and eggshell powder. [11]

Amrutha K Francis et al., (2017) studied on the effect of replacement of Portland cement by sugar cane bagasse ash (SCBA) and eggshell powder on high performance concrete (HPC). This study tries to examine the mechanical properties of HPC with different mix proportion.Here cement is replaced partially with ESP as $2.5,5$ and 7.5\% by weight of cement and 5, 10 and $15 \%$ of SCBA respectively, from this mechanical property such as compressive and tensile strengths are examined. Final result shows that one with 5\% ESP and 10\% SCBA produced the preeminent HPC in the experiment. [12]

Ranjith Kumar et al., (2017)experimentally studied on concrete using coconut shell ash (CSA) and egg shell powder. This study explores the use of ESP and CSA from 5 to $25 \%$ replacement of cement in M30 grade concrete. The mechanical properties are evaluated at 7, 14, 21 and $28^{\text {th }}$ day's test. Due to its high pozzolanic activity both strength and durability of concrete are enriched and this may increase the strength of concrete against cracking. It was observed that up to $10 \%$ replacement can be used on concrete. [13]

Anisha et al. (2017) experimentally investigated on effect of fly ash on eggshell concrete. In the present study, concrete cubes of grade M30 and M40 were prepared in the laboratory by 
replacing the fine aggregate with fly ash and ESP at combined proportions of $0,7,14,21,28,35$ and $42 \%$ by weight. Study on strength properties are conducted at $7^{\text {th }}$ and $28^{\text {th }}$ day's age test. Outcome of this investigation suggest that fly ash and eggshell could be very conveniently used in structural concrete. [14]

Bandhavya et al., (2017) experimentally studied on partial replacement of cement with eggshell powder in concrete. In this paper eggshell is replaced by $0,5,10$ and $15 \%$ of cement and the tests were carried out to find best combination which results in optimum strength. The result shows that, ESP replacement greater than 10\% had minor strength than conventional concrete and this can be augmented if the concrete is used with reinforcement. [15]

Parthasarathi et al., (2017) experimentally studied on partial replacement of cement with eggshell powder and silica fume. The goal of this research demonstrates the strength features by using ESP at 5, 10 and 15\% with 2.5, 5 and 7.5\% silica fume as additional to cement. It shows that the compressive strength of concrete with ESP as cement replacement material increases up to $15 \%$ without silica fume.Addition of silica fume also improves the potency but in expensive point of view only the ESP replacement is enough adequate for getting superior strength. [16]

Afolayan et al., (2017) experimentally investigated on the effect of partial replacement of cement with eggshell ash (ESA) on the rheological properties of concrete. This research presents the experimental results by using ESA as a replacement of 5 to $30 \%$. From the consequences of hardened concrete it has been observed that increase in the percentage of ESA leads to decrease in the compressive strength. [17]

Vijayvenkatesh Chandrasekaran et al.,(2018) experimentally investigated on partial replacement of cement with eggshell ash in concrete. The ESA powder in this project is replaced by 20,30 and $40 \%$ to cement by weight. It is more reliable to mixing ratios for M20 grade of concrete. From the experimental test it is been noted that replacement of ESA at 30 and $40 \%$ gives an end result in strength feature. [18]

Haripriya et al., (2018) experimentally studied on partial replacement of cement with eggshells powder and aggregates with coconut shells. In this paper ESP is used by 0, 5, 10 and $15 \%$ replacement of cement with natural coarse aggregate. The concrete is casted with mix proportion of 1:1.5:3 and the tests are been determined at the curing age of 7,14 and 28 days. Final result concluded that the strength is increased on $10 \%$ replacement up to 7 days test and gets decreased from 14 to 28 days. The cubes with replacement of cement at $15 \%$ act as a brittle material when compared to 5 and $10 \%$. The optimum strength obtained is $12 \%$ which is greater than conventional concrete. [19]

Baskar et al., (2018) experimentally studied on partial replacement of cement with glass powder and eggshell powder. The aim of this study experimentally investigates the effect on partial replacement of cement by glass powder and ESP at 20, 30 and 40\%. Instead of using a piece of glass powder as an alternative to cement, egg shell powder is clear due to its increase in workload and strength. [20]

Ramathilagam et al., (2018) has done an experimental investigation on eggshell powder as a partial replacement of cement in paver block. Here cement is partially replaced by ESP at 5\% intervals from 0 to $25 \%$. The main function of this admixture is to reduce the water cement ratio and enhance workability in paver block. After the curing process of 7 days and 28 days it is checked for its strength characteristics. It showed that ESP can be advantageous if it was replaced at $10 \%$ by weight of cement. [21]

Pradeep Sharma et al., (2018) have undergone an experimental investigation on partial replacement of cement with eggshell powder and fine aggregate with copper slag in concrete. On this project the copper slag is replaced with sand at 10 and $40 \%$ and the optimum proportion was 
found by conducting the following tests. The strength is been increased with $12 \%$ of cement by ESP and $30 \%$ of fine aggregate by copper slag in concrete. It is also found that, addition of super plasticizer into concrete shows small change in strength properties. [22]

\section{CRITICAL REMARKS}

By the above investigations endured on strength and structural characteristics of conventional cement concrete that are evenly proportioned with calcium rich eggshell powder and their potential feasibilities were exemplified and are concluded.

1. ESP about $10 \%$ to $15 \%$ is effective for replacement and on further increasing the percentage of ESP decreases the compressive strength and this can be augmented if the concrete is used with reinforcement.

2. The replacement of 5\% ESP with $10 \%$ micro silica, fly ash and saw dust contributes high strength of hardened concrete when compared to control concrete and addition of fly ash along with ESP up to $15 \%$ is beneficial than control concrete. Increase in workability and density was found with addition of fly ash to optimum ESP concrete.

3. The absorption property decreased with decrease in permeable voids.

4. Sorptivity decreased with strength and increased with water absorption.

5. Optimum strength was obtained at $20 \%$ of fine aggregate replaced by ESP and $0.2 \%$ of polypropylene fiber by the weight of concrete for M20 grade.

6. $5 \%$ ESP and 10\% SCBA, CSA produced the preeminent HPC in the experiment.

7. The replacement of ESA at 30 and $40 \%$ gives an end result in strength feature, further increase in the percentage of ESA leads to decrease in the compressive strength.

8. Cost wise ESP is inexpensive.

\section{REFERENCES}

1. D.Gowsika, S.Sarankokila and K.Sargunan "Experimental investigation of egg shell powder as partial replacement with cement in concrete", International Journal of Engineering Trends and Technology (IJETT) Volume 14, Number 2, Aug 2014.

2. Amarnath Yerramala, "Properties of concrete with eggshell powder as cement replacement", The Indian Concrete Journal - October 2014.

3. Mohd Ali Khaled, D Raju "Study the behavior of egg shell powder as partial replacement with cement in concrete" IJECEC, Volume 3 Issue 5, 2014.

4. Praveen Kumar R, Vijaya Sarathy R "Experimental study on partial replacement of cement with egg shell powder", International journals of innovations in engineering and technology (IJIET). Vol 5, Issue 2, April 2015.

5. Dhanalakshmi M, Dr Sowmya N J Ass Prof, Dr Chandrasekar A "A comparative study on egg shell concrete with partial replacement of cement by fly ash", International Journal of Engineering Research \& Technology (IJERT) Vol. 4, Issue 05, May 2015.

6. Mohamed Ansari M, Dinesh Kumar M, Milan Charles J, Dr Vani G "Replacement of cement using eggshell powder", SSRG International Journal of Civil Engineering (SSRG - IJCE), Volume 3, Issue 3, March 2016.

7. Monisha $\mathrm{T}$ "Experimental investigation on concrete using eggshell powder and polypropylene fibre”, International Journal of Advanced Engineering Research and Technology (IJAERT) Volume 4 Issue 4, April 2016. 
8. Nurul Shahadahtul Afizah Asman "Mechanical properties of concrete using eggshell ash and rice husk ash as partial replacement of cement", ISCEE 2016.

9. Bysani Mythili "A study on limited substitution of egg shell powder with cement in concrete" International journal of scientific engineering and technology research. Vol 6, Issue 4, February 2017.

10. Divya B "Investigation on cement concrete at mixed with egg shell powder" International Journal of Innovative Research in Science, Engineering and Technology.Vol. 6, Issue 3, March 2017.

11. Priyanka.M "Experimental investigation of eggshell powder and rice husk ash as partial replacement of cement", International Journal of Advanced Research Trends in Engineering and Technology (IJARTET) Vol. 4, Special Issue 11, March 2017.

12. Amrutha K Francis“Study on the effect of replacement of portland cement by sugar cane bagasse ash and egg shell powder on HPC". International Journal of Scientific \& Engineering Research,Volume 8, Issue 3, March-2017.

13. R. Ranjith Kumar, "An experimental study on concrete using coconut shell ash and egg shell powder”, South Asian Journal of Engineering and Technology Vol.3, No.7 Apr 2017.

14. G. Anisha "An experimental investigation on effect of fly ash on egg shell concrete", International Journal of Trend in Scientific Research and Development, Volume 1, June 2017.

15. Bandhavya G B"An experimental study on partial replacement of cement with egg shell powder in concrete" International Research Journal of Engineering and Technology (IRJET) Volume: 04 Issue: 06 | June -2017.

16. N. Parthasarathi "Experimental study on partial replacement of cement with egg shell powder and silica fume" Vol. 10 April - June 2017.

17. Afolayan J. O. "Experimental Investigation of the Effect of Partial Replacement of Cement with Eggshell Ash on the Rheological Properties of Concrete", International Journal of Engineering and Applied Sciences (IJEAS) Volume-4, Issue-12, December 2017.

18. Vijayvenkatesh Chandrasekaran "Experimental Investigations of Partial Replacement of Cement with Egg Shell Ash in Concrete", International Journal of Innovative Research in Science, Engineering and Technology, Vol. 7, Issue 3, March 2018.

19. V Haripriya "An experimental study on partial replacement of cement with eggshells powder and aggregates with coconut shells", International Journal of Modern Trends in Engineering and Research (IJMTER) Volume: 5, Issue: 03, March 2018.

20. A.Baskar "Experimental study on partial replacement of cement with glass powder and egg shell powder",International Journal of Science and Engineering Research (IJOSER), Vol 6, Issue 4 April 2018.

21. Ramathilagam.B.H "An experimental investigation of eggshell powder as a partial replacement of cement in paver block", Research article, Vol 8 Issue no 4. Apr 2018.

22. Pradeep Sharma "Experimental investigation on partial replacement of cement with egg shell powder and fine aggregate with copper slag in concrete", International Journal For Technological Research In Engineering Volume 5, Issue 10, June 2018. 